\title{
A single-point mutation in HCF causes temperature-sensitive cell-cycle arrest and disrupts VP16 function
}

\author{
Hiroshige Goto, ${ }^{1,2}$ Seiichi Motomura, ${ }^{1,3}$ Angus C. Wilson, ${ }^{5,6}$ Richard N. Freiman, ${ }^{5,7}$ \\ Yusaku Nakabeppu, ${ }^{4}$ Kohtaro Fukushima, ${ }^{1}$ Masatoshi Fujishima, ${ }^{2}$ Winship Herr, ${ }^{5}$ and \\ Takeharu Nishimoto ${ }^{1,8}$ \\ ${ }^{1}$ Department of Molecular Biology, ${ }^{2}$ Internal Medicine II, ${ }^{3}$ Internal Medicine III, ${ }^{4}$ Department of Biochemistry Medical \\ Institute of Bioregulation, Graduate School of Medical Science, Kyushu University, 3-1-1 Maidashi, Higashi-ku, Fukuoka \\ 812, Japan; ${ }^{5}$ Cold Spring Harbor Laboratory, Cold Spring Harbor, New York 11724 USA, ${ }^{7}$ Graduate Program in Genetics, \\ State University of New York at Stony Brook, Stony Brook, New York 11794 USA
}

The temperature-sensitive BHK21 hamster cell line tsBN67 ceases to proliferate at the nonpermissive temperature after a lag of one to a few cell divisions, and the arrested cells display a gene expression pattern similar to that of serum-starved cells. The temperature-sensitive phenotype is reversible and results from a single missense mutation-proline to serine at position 134-in HCF, a cellular protein that, together with the viral protein VP16, activates transcription of herpes simplex virus (HSV) immediate-early genes. The tsBN67 HCF mutation also prevents VP16 activation of transcription at the nonpermissive temperature. The finding that the same point mutation in HCF disrupts both VP16 function and the cell cycle suggests that HCF plays a role in cell-cycle progression in addition to VP16-dependent transcription.

[Key Words: tsBN67; HCF protein; VP16 function; $\mathrm{G}_{0} / \mathrm{G}_{1}$ cell cycle arrest; transcription]

Received November 14, 1996; accepted in revised form February 7, 1997.

Conditional mutations, particularly temperature-sensitive mutations, have been valuable tools for clarifying cell-cycle regulation in yeast as well as mammalian cells (for review, see Marcus et al. 1985). Previously, we have isolated a series of temperature-sensitive cell-proliferation mutants from the hamster BHK21 cell line (Nishimoto and Basilico 1978; Nishimoto et al. 1982). Following mutagenesis with $N$-methyl- $N^{\prime}$-nitro- $N$-nitrosoguanidine, mutants that proliferate at the permissive temperature of $33.5^{\circ} \mathrm{C}$ but not at the nonpermissive temperature of $39.5^{\circ} \mathrm{C}$ were concentrated through multiple rounds of negative selection with the cytotoxic base analog 5-fluoro-2-deoxyuridine to eliminate proliferating cells at the elevated temperature. Based on the ability of hybrid cells created by the fusion of different mutant lines to grow at the nonpermissive temperature, these temperature-sensitive lines have been classified into 25 complementation groups (Nishimoto and Basilico 1978; Nishimoto et al. 1982).

To identify the genes affected by these mutations, human DNA has been used to complement the hamster-

\footnotetext{
${ }^{6}$ Present address: Department of Microbiology and Kaplan Cancer Center, New York University School of Medicine, New York, New York 10016 USA.

${ }^{8}$ Corresponding author.

E-MAIL tnishi@molbiol.med.kyushu-u.ac.jp; FAX 81-92-632-2373.
}

cell proliferation defect, and the complementing human genes isolated from the rescued cells by hybridization with a human-specific DNA probe (Kai et al. 1986; Watanabe et al. 1991; Nakashima et al. 1993). Subsequently, the mutation responsible for the temperature-sensitive growth-arrest phenotype has been revealed by comparing the wild-type and temperature-sensitive cDNA sequence of the homologous hamster gene (Uchida et al. 1990; Nakashima et al. 1993; Watanabe et al. 1993).

One of our temperature-sensitive BHK21 mutants, called tsBN67, is the sole member of a complementation group displaying unique properties (Nishimoto and Basilico 1978|. First, unlike other isolates, tsBN67 cells can proliferate normally for 1-2 days at the nonpermissive temperature. Second, once arrested at the nonpermissive temperature, the cells displayed high viability and could be rescued efficiently by transfer to the permissive temperature. The nature of the defect in tsBN67 cells is not known, however.

During herpes simplex virus (HSV) infection, viral immediate-early (IE) gene expression is activated by a complex of regulatory proteins that includes two cellular proteins, HCF (also termed C1, VCAF, and CFF) and Oct-1, and the viral transactivator VP16 (for review, see Thompson and McKnight 1992; O'Hare 1993). VP16 (also known as Vmw65, $\alpha \mathrm{TIF}$, and ICP25) is a virion protein that is released into the cell upon infection. After release, it associates with HCF to form a heteromeric 
complex that binds to the transcription factor Oct-1 on the cis-regulatory target of VP16 activation, the TAATGARAT motif /Gerster and Roeder 1988; Kristie et al. 1989; Katan et al. 1990; Kristie and Sharp 1990; Xiao and Capone 1990; Stern and Herr 1991).

Unlike Oct-1, a known transcription factor (for review, see Herr 1992), the cellular role of HCF is unknown. Mature $\mathrm{HCF}$ is a nuclear protein that is expressed broadly in proliferating cells (Kristie et al. 1995; Wilson et al. 1995a) and consists of a complex of associated polypeptides (Kristie and Sharp 1993; Wilson et al. 1993a), that represent amino- and carboxy-terminal fragments derived by highly specific proteolytic processing of a large $300-\mathrm{kD}$ precursor protein (Wilson et al. 1993a, 1995b; Kristie et al. 1995). Although the function of HCF in cells is unknown, it is likely to be important because HCF activity is conserved among vertebrate and invertebrate organisms (Kristie et al. 1989; Wilson et al. 1993b).

We show here that a single missense mutation in HCF is responsible for the tsBN67 defect. At the nonpermissive temperature, tsBN67 cells resemble cells arrested in $\mathrm{G}_{\mathrm{O}} / \mathrm{G}_{1}$ and fail to support transcriptional activation by VP16. These results indicate that HCF is important for maintenance of cellular as well as viral proliferation.

\section{Results}

Figure 1 shows a comparison of the growth rates of the parental BHK21 and temperature-sensitive tsBN67 cells at the permissive and nonpermissive temperatures. At $33.5^{\circ} \mathrm{C}$, the permissive temperature, both cell lines grew at a similar rate, doubling every $18-20 \mathrm{hr}$ (solid symbols). At $39.5^{\circ} \mathrm{C}$, the nonpermissive temperature, however, the growth kinetics of the two cell lines differed from one another (open symbols). The BHK21 cells proliferated more rapidly at $39.5^{\circ} \mathrm{C}$ than at $33.5^{\circ} \mathrm{C}$, doubling about every $12 \mathrm{hr}$. In contrast, although for the first $36 \mathrm{hr}$ at $39.5^{\circ} \mathrm{C}$ the tsBN67 cells proliferated as they had at $33.5^{\circ} \mathrm{C}$, after $36 \mathrm{hr}$ they ceased to proliferate. Once arrested, the overall cell number remained relatively constant. These cells survived for extended periods at the elevated temperature; for example, $92 \%$ and $70 \%$ of tsBN67 cells maintained at $39.5^{\circ} \mathrm{C}$ for 2 and 4 days, respectively, produced colonies when transferred to $33.5^{\circ} \mathrm{C}$ (data not shown; see also Nishimoto and Basilico 1978). Thus, the temperature-sensitive tsBN67 cell-arrest phenotype is delayed by one to a few cell doublings and is reversible.

\section{The HCF gene complements the tsBN67 phenotype}

To identify the mutated gene responsible for the tsBN67 phenotype, high molecular weight human HeLa-cell DNA was transfected into tsBN67 cells along with the neomycin-resistant (neo ${ }^{\mathrm{r}}$ ) vector pSV2neo as described previously (Watanabe et al. 1991). As a negative control, tsBN67 genomic DNA was cotransfected with pSV2neo. Transformants were selected in the presence of G418 either at $33.5^{\circ} \mathrm{C}$, or at $39.5^{\circ} \mathrm{C}$. The tsBN67- and HeLa-

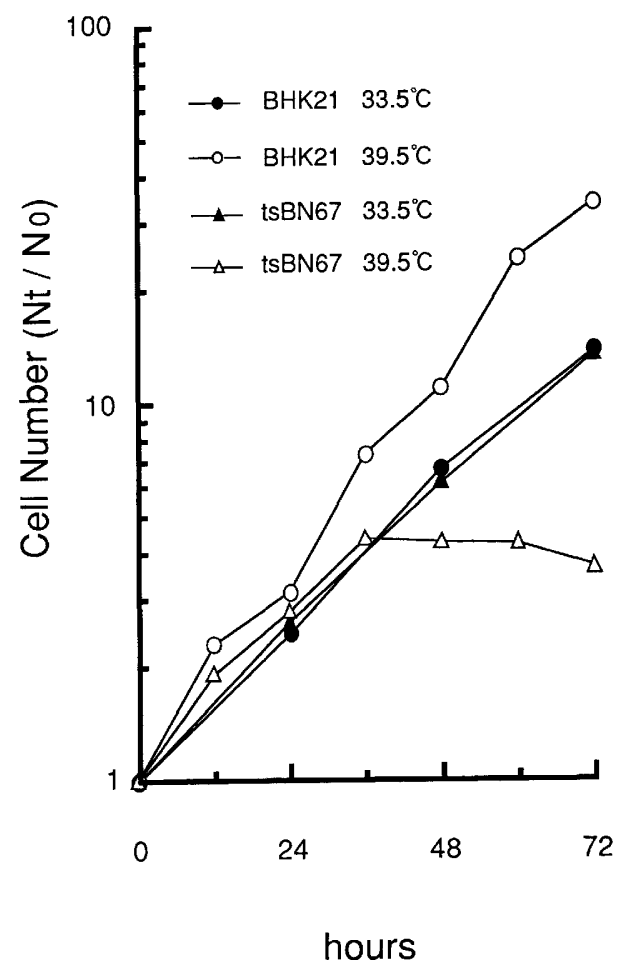

Figure 1. Hamster tsBN67 cells cease proliferating at $39.5^{\circ} \mathrm{C}$ after a lag of $\sim 36$ hrs. Wild-type $(\bullet, O)$ and tsBN67 $(\mathbf{\Delta}, \triangle)$ BHK21 cells were seeded at densities of $1 \times 10^{5} / 150-\mathrm{mm}$ dish and $4 \times 10^{5} / 150-\mathrm{mm}$ dish, respectively, and incubated at $33.5^{\circ} \mathrm{C}$ for 2 days. After refeeding, half of the cultures were shifted to $39.5^{\circ} \mathrm{C}$. At the indicated times, cells were harvested and counted. The ratio of cell number at each time point relative to the initial number at the temperature shift is plotted against the time of incubation. $(O, \Delta) 39.5^{\circ} \mathrm{C} ;(\bullet, \Delta) 33.5^{\circ} \mathrm{C}$. The total cell number is a combination of floating and adherent cells.

cell DNAs displayed the same transformation efficiency at $33.5^{\circ} \mathrm{C}$ (Table 1). However, at $39.5^{\circ} \mathrm{C}$ the tsBN67 DNA failed to rescue the tsBN67 phenotype, whereas the HeLa-cell DNA yielded several ts ${ }^{+}$colonies (primary transformants). Total cellular DNA prepared from one of the primary transformants, designated BN67-V-3, was transfected into the original tsBN67 cells, to enrich for human DNA essential for complementing the tsBN67 mutation.

Using a $\lambda$ phage vector, we prepared a library of genomic DNA from the secondary $\mathrm{ts}^{+}$transformant BN67-V3-2, and screened for clones containing human DNA by hybridization with the human-specific Alu repeat probe. Three overlapping genomic DNA clones were isolated, spanning $\sim 35 \mathrm{~kb}$ of human sequence (data not shown). No $\mathrm{ts}^{+}$transformants were obtained upon transfection of any one of the individual clones. However, when clones $5 / \lambda$ DashII and $8 / \lambda$ DashII were transfected together, $\mathrm{ts}^{+}$ colonies appeared and at a higher efficiency than with total cellular DNA (Table 1; cf. experiments 1 and 2). These results indicated that the tsBN67-cell defect was complemented by either a single open reading frame (ORF) that was reconstructed by recombination of co- 
Table 1. Rescue of the mutant tsBN67 phenotype by DNA transfection

\begin{tabular}{|c|c|c|}
\hline \multirow{2}{*}{$\begin{array}{l}\text { Donor DNA } \\
(+\mathrm{pSV} 2 \mathrm{neo})\end{array}$} & \multicolumn{2}{|c|}{$\begin{array}{l}\text { Number of colonies per } \\
2 \times 10^{5} \text { tsBN67 cells }\end{array}$} \\
\hline & $\mathrm{ts}^{+}, \mathrm{neo}^{\mathrm{r}}$ & neo \\
\hline \multicolumn{3}{|l|}{ Experiment 1} \\
\hline tsBN67 & 0.00 & 452 \\
\hline HeLa & 0.25 & 452 \\
\hline BN67-V-3 (1st) & 0.60 & 443 \\
\hline BN67-V-3-2 (2nd) & 1.20 & 471 \\
\hline \multicolumn{3}{|l|}{ Experiment 2} \\
\hline $5 / \lambda$ DashII & 0.00 & 160 \\
\hline $8 / \lambda$ DashII & 0.00 & 164 \\
\hline $5 / \lambda$ DashII $+8 / \lambda$ DashII & 13.00 & 164 \\
\hline \multicolumn{3}{|l|}{ Experiment 3} \\
\hline $\mathrm{c} 23 / \mathrm{pcDL}-\mathrm{SR} \alpha \mid+1$ & 29.00 & 158 \\
\hline $\mathrm{c} 23 / \mathrm{pcDL}-\mathrm{SR} \alpha \mid-1$ & 0.00 & 175 \\
\hline
\end{tabular}

Donor DNAs were transfected into tsBN67 cells along with pSV2neo as described in Materials and Methods. The sources of DNA were as follows: (Experiment 1) High molecular weight chromosomal DNA prepared from HeLa and tsBN67 cells, and from the primary (1st) and the secondary (2nd) ts ${ }^{+}$tsBN67 transformants; (experiment 2) $\lambda$ phage clones containing human genomic DNA derived from the secondary (2nd) $\mathrm{ts}^{+}$cells; (experiment 3), hamster cDNA clones inserted into the mammalian expression vector, pcDL-SR $\alpha$ in either the sense $(+\}$ or antisense $(-)$ orientation. Transformants were selected in the presence of $\mathrm{G} 418(800 \mu \mathrm{g} / \mathrm{ml})$ at $33.5^{\circ} \mathrm{C}\left(\mathrm{neo}^{\mathrm{r}}\right)$ or at $39.5^{\circ} \mathrm{C}\left(\mathrm{ts}^{+}, \mathrm{neo}^{\mathrm{r}}\right)$ as described in Materials and Methods.

transfected genomic DNA in vivo or by two ORFs, one on each $\lambda$ phage genomic DNA fragment. The results described below indicate that the complementing ORF was reconstructed by recombination after transfection.

An Alu-free DNA probe from clone 5/גDashII recognized an $\sim 8.3-\mathrm{kb}$ transcript common to both HeLa and BHK21 cells (data not shown). This probe was used to screen a hamster BHK21 cDNA library (Seki et al. 1992); and a series of clones spanning a total of $8.3 \mathrm{~kb}$ (and contained in the two $\lambda$ phage clones $5 / \lambda$ DashII and $8 / \lambda$ DashII, described abovel was obtained. Sequence analysis revealed that these cDNAs encoded the hamster homolog of the human HCF gene (Wilson et al. 1993a).

To confirm that expression of the single HCF ORF was responsible for rescue of the tsBN67 mutation defect, a cDNA fragment (c23) containing a complete 6.3-kb ORF was subcloned into the mammalian expression vector pcDL-SR $\alpha$ in both the sense [c23/pcDL-SR $\alpha(+)]$ and the antisense [c23/pcDL-SR $\alpha(-)$ ] orientation. When transfected into tsBN67 cells, only the sense orientation construct converted tsBN67 cells to the $\mathrm{ts}^{+}$phenotype (see Table 1, experiment 3). This experiment demonstrates that the expression of wild-type hamster HCF cDNA alone is sufficient to complement the tsBN67 mutation.

\section{HCF is highly conserved between hamsters and} humans

Figure $2 \mathrm{~A}$ shows an alignment of the deduced hamster and human HCF amino acid sequences, and Figure 2B shows a diagram of the hamster HCF ORF. The longest original human HCF ORF encoded 2035 amino acids (Wilson et al. 1993a). Some of the hamster cDNAs, however, revealed a new mRNA splicing variant that extends one exon, inserting 43 codons after codon 1508 of the hamster HCF ORF. Analysis of the original collection of human HCF cDNAs (Wilson et al. 1993a) identified a corresponding 44-codon extension in two of nine cDNA clones spanning this region of the HCF ORF (after human HCF codon 1499; data not shown); this sequence extension, arising through alternate splice acceptor site selection, has also been reported by Frattini et al. (1996). The extended hamster and human HCF sequences are included in Figure 2.

The human HCF ORF can be broadly divided into three regions: a central region containing six near-perfect 26-amino-acid HCF repeats responsible for HCF processing (Wilson et al. 1995b), and amino- and carboxy-terminal regions that remain associated with one another after HCF cleavage (Wilson et al. 1993a). The amino-terminal regions (residues 1-1009 in both hamster and human HCF) and carboxy-terminal regions (residues 1448-2090 in hamster HCF and 1439-2079 in human HCF) of hamster and human HCF are highly conserved: The aminoterminal sequences are $>98 \%$ identical 15 differences in 1009 positions), and the carboxy-terminal sequences are $95 \%$ identical ( 34 differences in 643 positions).

In the central HCF repeat region, there is only one difference (in HCF repeat 3 ) among the six near-perfect HCF repeats. This high level of conservation is consistent with the strict sequence requirements for efficient proteolytic cleavage (Wilson et al. 1995b). The intervening sequences, which are frequently absent in mature HCF, are relatively hypervariable, however, displaying only $67 \%$ identity. Indeed, the hamster sequence reveals a third imperfect HCF repeat (designated HCF repeat $4 B$ ). By analogy to the imperfect and inactive human HCF repeat 7 (Wilson et al. 1995b), the imperfect hamster HCF repeat $4 \mathrm{~B}$ is probably not active in HCF processing. The lack of high sequence conservation in the regions between HCF repeats suggests that these sequences are not critical for HCF function during or after processing.

The tsBN67 HCF gene contains a single-point mutation, which is responsible for the temperature-sensitive phenotype

To determine whether tsBN67 cells contain a mutation in the hamster HCF gene, we isolated a series of HCF cDNA fragments that span the entire tsBN67 HCF ORF by RT-PCR. These HCF fragments were sequenced and compared to the parental BHK21-HCF sequence. Of the 6270-base hamster HCF ORF, only a single-base substitution was identified: a $\mathrm{C} \rightarrow \mathrm{T}$ transition at the first position of codon 134 (indicated by the arrow in Fig. 2A). The nucleotide sequence of this and the flanking codons is shown in Figure 2B, together with an illustration of landmarks in the HCF ORF (Wilson et al. 1993a). This single $\mathrm{C} \rightarrow \mathrm{T}$ transition mutation, which is consistent with the tsBN67-cell mutagenesis protocol using 
A

MASAVSPANLPAVLLQPRWKRVVGWSGPVPRPRHGHRAVAIKELIVVFGGGNEGIVDELHVYNTATNQWFIPAVRGDIPPGCAAYGFVCDGTRLLVFGGM 100 ESHTAVVYTEKDNKKSKLVIYGGMSGCRLGDLWTLDIETLTWNKPSLSGVAPLPRSLHSATTIGNKMYVFGGWVPLVMDDVKVATHEKEWKCTNTLACLN 300 LDTMAWETIIMDTLEDNIPRARAGHCAVAINTRLYIWSGRDGYRKAWNNQVCCKDLWYLETEKPPPPARVQLVRANTNSLEVSWGAVATADSYLLQLQKY 400 DIPATAATATSPTPNPVPSVPANPPKSPAPAAAAPAVQPLTQVGITLVPQAAAAPPSTTTIQVLPTVPGSSISVPTAARAQGVPAVLKVTGPQATTGTPL VTMRPAGQAGKAPVTVTSLPASVRMVVPTQSAQGTVIGSNPQMSGMAALAAAAAATOKIPPSSAPTVLSVPAGTTIVKTVAVTPGTTTLPATVKVASSPV 600 MVSNPATRMLKTAAAQVGTSVSSAANTSTRPIITVHKSGTVTVAQQAQVVT'TVVGGVTKTITLVKSPISVPGGSALISNLGKVMSVVQTKPVQTSAVTGQ 700 ASTGPVTQIIQTKGPLPAGTILKLVTSADGKPTTIITTTQASGAGSKPTILGISSVSPSTTKPGTTTIIKTIPMSAIITQAGATGVTSTPGIKSPITIIT 800 TKVMTSGTGAPAKIITAVPKIATGHGQQGVTQVVLKGAPGQPGAILRTVPMSGVRLVTPVTVSAVKPAVTTLVVKGTTGVTTLGTVTGTVSTSLAGAGAH STSASLATPITTLGTIATLSSQVINPTAITVSAAQTTLTAAGGLTTPTITMOPVSQPTQVTLITAPSGVEAQPVHDLPVSILASPTTEQPTATVTIADSG 1000

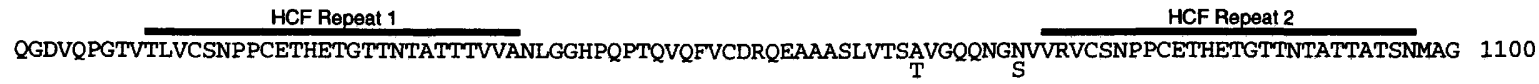
HCF Repeat 3 HCF Repeat 4A QHGCSNPPCETHETGTTSTATTAMSSMGTGQQRDTRHT--SSNPTVVRITVAPGALERTQGTVKPQCOTQQANMTNTTMTVQATRSPCPAGPLLRPSVAL 1198 EAGNHSPAFVQLALPSVRVGLSGPSNKDMPTGHQLETYHTYTTNTPTTALSTMGAGELGTARLIPTSTYESLQASSPSSTMTMTALEALLCPSATVTQVC
P GR

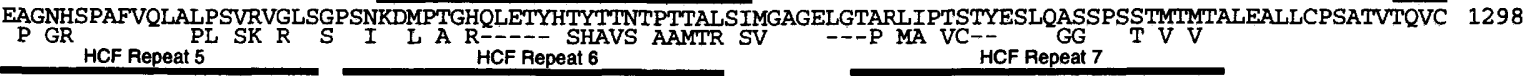
SNPPCETHETGTTNTATTSNAGSAQRVCSNPPCETHETGTTHTATTATSNGGAGQPEGGQQPAGGRPCETHQTTSTGTTMSVSVGALLPDATPSHGTLES $\mathrm{P}$ PA HCF Repeat 8 GLEVVAVSTVTSQAGATLLASFPTQRVCSNPPCETHETGTTHTATTVTSNMSSNQDPPPAASDQGEVVSTQGDSANITSSSGITTTVSSTLPRAVTTVTQ 1498 A APS P TA P Alternative splice (1509-1551) STPVPGPSVPNTISSLTET-PGALTSEVPIPATITVTIANTETSDMPFSAVDILQPPEELQVSPGPRQQLPPRQLLQSASTPLMGESSEVLSASQTPELQA $\mathrm{K}$ A $\underset{\text { E }}{\text { AVDLSSTGPSSQEPTSSAVATVVVQPPPPTQSEVDQLSLPQELMAEAQAGTTTLMVTGLTPEELAVTAAAEAAAQAAATEEAQALAIQAVLQAAQQA } 1697}$ VMAGTGEPMDTSEAAAAVTQAELGHLSAEGQEGQATTIPIVLTQQELAALVQQQQQLQEVQAQAQQQHHLPTEALAPADSLNDPSIESNCLNELASAVPS 1797 TVALLPSTATESLAPSNTFVAPQPVVVASPAKMQAAATLTEVDNGIESLGVKPDLPPPPSKAPVKKENQWFDVGVIKGTSVMVTHYFLPPDDAVQSDDDS 1897 $\underset{V}{\text { GTIPDYNQLKKQELQPGTAYKFRVAGINACGRGPFSEISAFKTCLPGFPGAPCAIKISKSPDGAHLTWEPPSVTSGKIIEYSVYLAIQSSQAGGEPKSST 1997 }}$ PAQLAFMRVYCGSPSCLVQSSSLSNAHIDYTTKPAIIFRIAARNEKGYGPATQVRWLQETSKDSSGTKPASKRPMSSPEMKSAPKKSKADGQ 2090

\section{B}

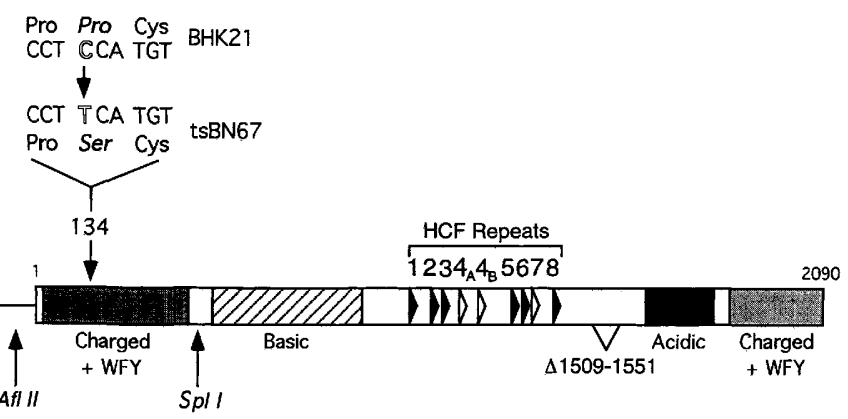

Figure 2. The hamster HCF gene is highly related to the human homolog and the mutant tsBN67 HCF gene contains a single missense mutation at position 134. (A) Comparison of the predicted hamster and human HCF amino acid sequences. The predicted sequence of wild-type BHK21 hamster HCF is shown, with residues that differ in human HCF (Wilson et al. 1993a) indicated below. The hamster sequence includes an additional 43 codons (codons 1509-1551); the corresponding human sequence (Frattini et al. 1996; this work) is included in the comparison. Heavy overlines indicate the HCF repeats; the light overline indicates the additional sequences owing to the alternative splice. ( $\downarrow)$ Amino acid 134, which is mutated in tsBN67 cells, is indicated. The nucleotide sequence of hamster HCF has been deposited in GenBank, accession number D45419. $\{B\}$ Location of the tsBN67 mutation in hamster HCF. The general organization of the hamster HCF ORF is shown. The single nucleotide change leading to a substitution of serine for proline at position 134 is indicated. To demonstrate that this single point mutation prevents complementation by the tsBN67 HCF cDNA, an AfIII-SplI fragment spanning this mutation, was exchanged for the wild-type HCF cDNA. 
$N$-methyl- $N^{\prime}$-nitro- $N$-nitrosoguanidine (Ito et al. 1994), converts the proline at position 134 to serine.

To confirm that we had identified the relevant mutation, a 1.1-kb wild-type AflII-SpII fragment, encompassing codon 134, was replaced by the corresponding tsBN67 fragment to create HCF-ml4. From HCF-ml4, we recreated the wild-type sequence in HCF-rl4 by replacing the tsBN67 AflII-SplI fragment with the corresponding wild-type fragment. Both plasmids were transfected separately into tsBN67 cells along with the pSV2neo marker and scored for colony formation at $33.5^{\circ} \mathrm{C}$ and $39.5^{\circ} \mathrm{C}$ in the presence of $\mathrm{G} 418$. The results of this experiment are shown in Table 2 . At $33.5^{\circ} \mathrm{C}$, there were similar numbers of neo ${ }^{\mathrm{r}}$ colonies in the two transfections, indicating comparable transfection efficiencies. In contrast, at $39.5^{\circ} \mathrm{C}$, colonies were identified only in the cells transfected with the HCF-r14 cDNA containing the wild-type BHK2l-derived AflII-SplI fragment, demonstrating that the single codon 134 point mutation in HCF-m 14 is sufficient to prevent complementation of the temperature-sensitive tsBN67 phenotype.

HCF expression in tsBN67 cells is normal at the nonpermissive temperature

The HCF protein is expressed as a $300-\mathrm{kD}$ precursor $\left(\mathrm{HCF}_{300}\right)$ that is processed by proteolytic cleavage into a series of amino-terminal $\left(\mathrm{HCF}_{\mathrm{N}}\right)$ and carboxy-terminal $\left(\mathrm{HCF}_{\mathrm{C}}\right)$ fragments (Wilson et al. 1993a). Despite cleavage, the majority of these fragments remain tightly but noncovalently associated (Wilson et al. 1993a, 1995b). To determine whether changes in HCF protein stability, processing, or HCF fragment coassociation in tsBN67 cells at the nonpermissive temperature might be responsible for the temperature-sensitive phenotype, we performed sequential immunoprecipitation and immunoblot analyses using $\mathrm{HCF}_{\mathrm{N}}$ and $\mathrm{HCF}_{\mathrm{C}}$ fragment-specific antibodies.

As shown in Figure 3, we compared HCF expression in wild-type BHK21 and tsBN67 cells incubated for $20 \mathrm{hr}$ at

Table 2. The tsBN67 P134S mutation prevents complementation of tsBN67 cells by hamster HCF

\begin{tabular}{|c|c|c|}
\hline \multirow{2}{*}{$\begin{array}{l}\text { Donor DNA } \\
(+ \text { pSV2neo })\end{array}$} & \multicolumn{2}{|c|}{$\begin{array}{l}\text { Number of colonies per } \\
2 \times 10^{5} \text { tsBN67 cells }\end{array}$} \\
\hline & $\mathrm{ts}^{+}, \mathrm{neo}^{\mathrm{r}}$ & neo ${ }^{r}$ \\
\hline HCF-m 14 & 0 & 236 \\
\hline HCF-rl4 & 25 & 228 \\
\hline
\end{tabular}

The wild-type $1.1 \mathrm{~kb}$ AflII-Spll HCF cDNA fragment in c23/ pcDL-SR $\alpha|+|$ was exchanged for the corresponding tsBN67 fragment, introducing the tsBN67 mutation into the wild-type BHK21 HCF cDNA (HCF-m14). Afterward, the AflII-SpII fragment of the HCF-m14 cDNA was exchanged with that of wildtype BHK21 HCF cDNA, reverting the mutated cDNA to the wild-type HCF sequence (HCF-r14). Both HCF-m14 and HCFr14 recombinant cDNAs were transfected separately into tsBN67 cells, along with pSV2neo as described in Materials and Methods. Transformants were selected in the presence of G418 $(800 \mu \mathrm{g} / \mathrm{ml})$ at $33.5^{\circ} \mathrm{C}\left(\mathrm{neo}^{\mathrm{r}}\right)$ and at $39.5^{\circ} \mathrm{C}\left(\mathrm{ts}^{+}\right.$, neo $\left.^{\mathrm{r}}\right)$.

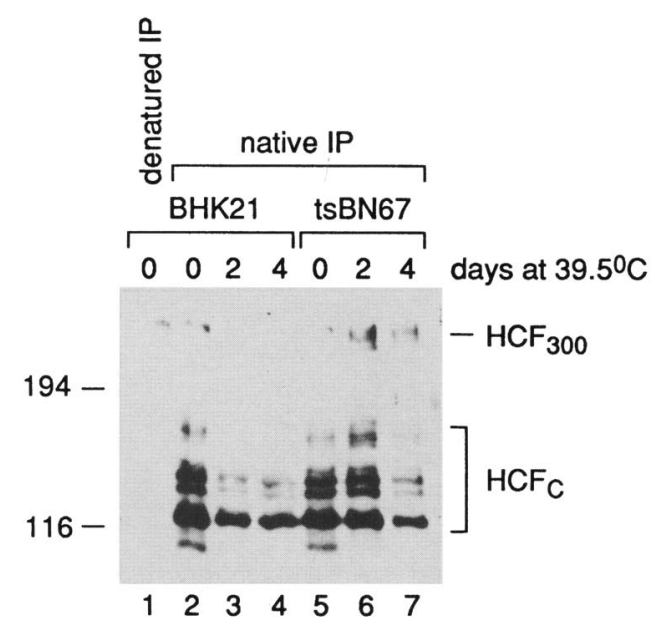

1: $\alpha H C F_{N}$ immunoprecipitation
2: $\alpha H C F_{C}$ immunoblot

Figure 3. The tsBN67 mutation does not alter the stability or coassociation of processed HCF fragments at the nonpermissive temperature. Equivalent numbers of $\mathrm{BHK} 21$ (lanes 1-4) and tsBN67 (lanes 5-7) cells were plated at $33.5^{\circ} \mathrm{C}$ and incubated for $20 \mathrm{hr}$ before being shifted to $39.5^{\circ} \mathrm{C}$. Whole-cell nuclear extracts were prepared immediately (lanes $1,2,5$ ), or after 2 (lanes 3,6 ) or 4 (lanes 4,7 ) days incubation at $39.5^{\circ} \mathrm{C}$. HCF polypeptides derived from equivalent numbers of cells were recovered by immunoprecipitation with the amino-terminal HCF-specific $\alpha \mathrm{HCF}_{\mathrm{N} 18}$ antiserum (see Materials and Methods). The sample in lane 1 was heat denatured prior to immunoprecipitation. The immunoprecipitates were fractionated on a $7 \%$ SDS-polyacrylamide gel, transferred to nitrocellulose filters, and probed with $\alpha \mathrm{HCF}_{\mathrm{C}}$ a rabbit polyclonal antisera directed against the carboxy-terminal region of HCF ( $\alpha \mathrm{rHCF}$ in Wilson et al. 1993a). Molecular mass markers are given in $\mathrm{kD}$. The relatively low level of HCF polypeptides in lane 3 was not reproducible.

$33.5^{\circ} \mathrm{C}$ and also subsequently for 2 or 4 days at $39.5^{\circ} \mathrm{C}$. HCF polypeptides were immunoprecipitated from cell extracts with an antipeptide antiserum directed against the very amino terminus of HCF $\left(\alpha \mathrm{HCF}_{\mathrm{N}}\right)$. The immunoprecipitates were then fractionated by polyacrylamide gel electrophoresis and probed by immunoblot with an antibody specific for the carboxy-terminal region of HCF $\left(\alpha \mathrm{HCF}_{\mathrm{C}}\right)$. In the sample shown in lane 1, the BHK21 cell extract was denatured prior to immunoprecipitation; the appearance of the full-length $\mathrm{HCF}_{300}$ polypeptide but not the processed $\mathrm{HCF}_{\mathrm{C}}$ fragments demonstrates that under these assay conditions, recovery of the $\mathrm{HCF}_{\mathrm{C}}$ fragments is dependent on noncovalent association with $\mathrm{HCF}_{\mathrm{N}}$ fragments.

The pattern of wild-type hamster $\mathrm{HCF}_{\mathrm{C}}$ polypeptides (lanes 2-4) is similar to the pattern of $\mathrm{HCF}_{\mathrm{C}}$ polypeptides observed with human HCF (Wilson et al. 1993a), indicating that hamster HCF processing is similar to that of human HCF. Although there are temperature-induced differences in the levels of $\mathrm{HCF}_{\mathrm{C}}$ fragments, the fragment patterns generated by both wild-type and tsBN67 cell extracts are similar (cf. lanes 2-4 and 5-7). Because 
the $\alpha \mathrm{HCF}_{\mathrm{N}}$ epitope lies amino-terminal of the tsBN67 mutation, and the $\mathrm{HCF}_{\mathrm{N}}$ region responsible for association with the $\mathrm{HCF}_{\mathrm{C}}$ fragments lies carboxy-terminal of the tsBN67 mutation (Wilson et al. 1995b), recovery of $\mathrm{HCF}_{\mathrm{C}}$ fragments with the $\alpha \mathrm{HCF}_{\mathrm{N}}$ antiserum demonstrates that the site of the tsBN67 mutation is intact. These results suggest that the tsBN67 mutation does not affect HCF protein stability, processing, and fragment coassociation.

\section{VP16 function is disrupted in tsBN67 cells at the nonpermissive temperature}

We next asked whether the tsBN67 HCF mutation af- fects activation of transcription by VP16. We compared the ability of VP16 to activate transcription from a $\beta$-globin promoter containing multiple tandem VP16 response elements during transient expression in wild-type and tsBN67 BHK21 cells at the permissive and nonpermissive temperatures as shown in the RNase protection assay of Figure 4A. In the absence of VP16, the levels of $\beta$-globin transcripts were very low in both wild-type and tsBN67 cells at both temperatures (Fig. 4A, lanes 1,3,5,7). In the wild-type cells, VP16 activated this $\beta$-globin promoter at both the permissive (15-fold activation) and nonpermissive (7-fold activation) temperatures (cf. lanes 1 and 2 , and 3 and 4). In tsBN67 cells, VP16 still activated
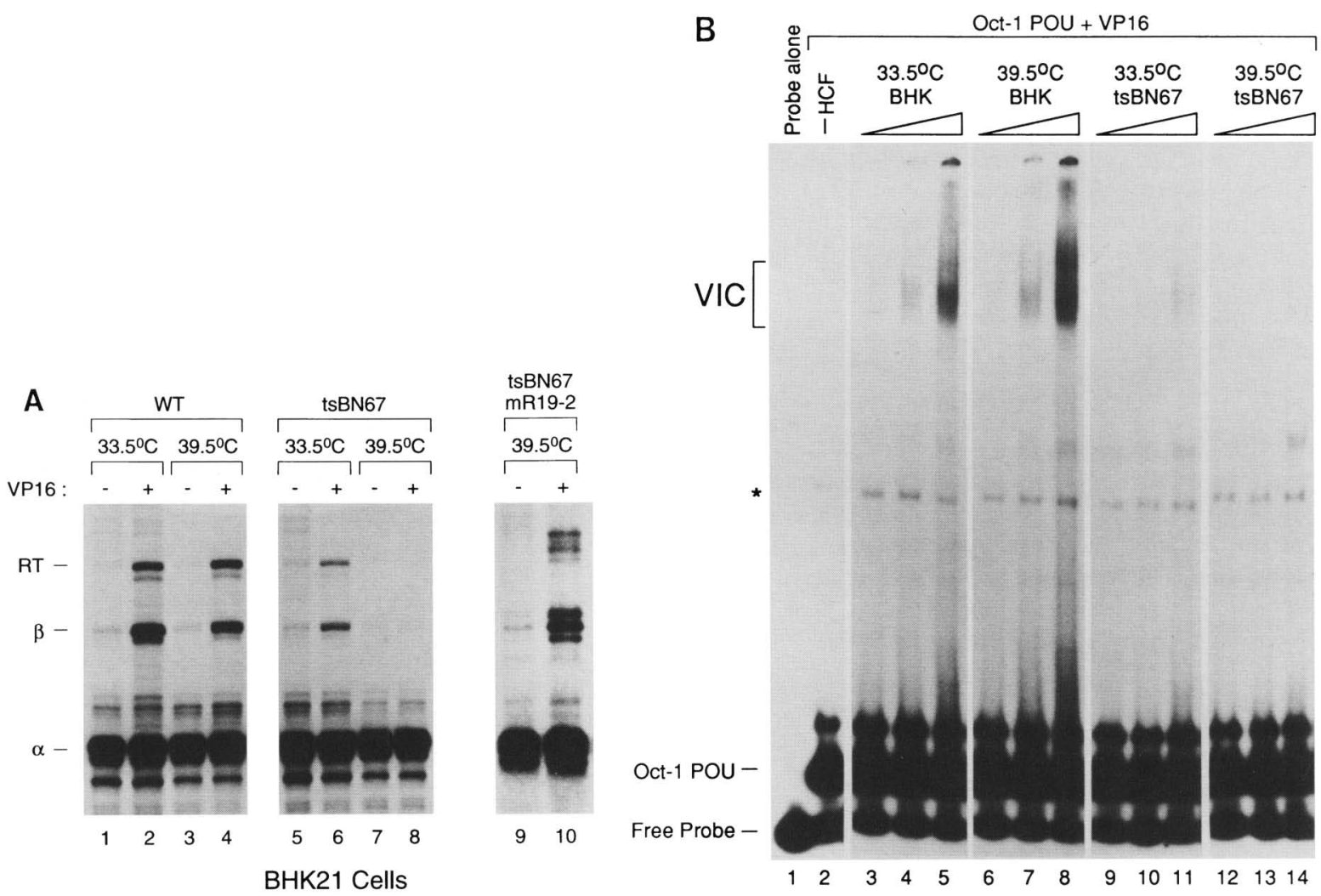

Figure 4. VP16 fails to activate transcription in tsBN67 cells at the nonpermissive temperature. $(A)$ Transcriptional activation by wild-type VP16. VP16-dependent activation of transcription was assayed by RNase protection after transient expression in wild-type BHK21 and tsBN67 cells as described in Materials and Methods. Expression was assayed in wild-type BHK21 cells at $33.5^{\circ} \mathrm{C}(1 \mathrm{anes} 1,2)$ or $39.5^{\circ} \mathrm{C}$ (lanes 3,4 ), tsBN67 cells at $33.5^{\circ} \mathrm{C}$ (lanes 5,6 ) and $39.5^{\circ} \mathrm{C}$ (lanes 7,8), and tsBN67 mR19-2 cells (a cell line rescued by transfection of the wild-type HCF gene) at $39.5^{\circ} \mathrm{C}$ (lanes 9,10). All samples contained the VP16-responsive $\beta$-globin-related reporter plasmid pU2/ $\beta$ 6xTAAT. The transfected cells for the samples in lanes $1,3,5,7$, and 9 lacked the VP16 expression plasmid, whereas those for the samples in lanes 2,4,6,8, and 10 contained the wild-type VP16 expression plasmid. The positions of the $\alpha$-globin $(\alpha)$, correctly initiated $\beta$-globin $(\beta)$, and $\beta$-globin readthrough (RT) transcripts are indicated to the left. $(B)$ VP16-induced complex assembly is severely reduced in extracts from tsBN67 cells. Extracts were prepared from BHK21 and tsBN67 cells maintained either at $33.5^{\circ} \mathrm{C}$ or $39.5^{\circ} \mathrm{C}$ and assayed for HCF activity in an electrophoretic mobility retardation assay, using bacterially expressed human Oct-1 POU domain, glutathione S-transferase VP16 (GST-VP16) fusion protein, and a labeled (OCTA ${ }^{+}$TAATGARAT probe from the HSV ICP0 promoter. The addition of recombinant human Oct-1 POU domain ensures that Oct-1 is not limiting in the assay. Unbound probe (lane 1), and probe mixed with Oct-1 POU domain and GST-VP16 (lane 2) are shown. Three different amounts of each extract (1, 3, and 10 $\mu \mathrm{g}$ ) were assayed as follows: Wild-type $\mathrm{BHK} 21$ cells grown at $33.5^{\circ} \mathrm{C}$ (lanes $\left.3-5\right), \mathrm{BHK} 21$ cells grown at $33.5^{\circ} \mathrm{C}$ and shifted to $39.5^{\circ} \mathrm{C}$ for $48 \mathrm{hr}$ (lanes $6-8$ ), tsBN67 cells grown at $33.5^{\circ} \mathrm{C}$ (lanes 9-11), and tsBN67 cells grown at $33.5^{\circ} \mathrm{C}$ and shifted to $39.5^{\circ} \mathrm{C}$ for $48 \mathrm{hr}$ (lanes 12-14|. In this experiment, the binding reactions were performed at $37^{\circ} \mathrm{C}$, but binding reactions performed at $4^{\circ} \mathrm{C}$ produced equivalent results (data not shown). The positions of the free probe, Oct-1 POU domain-DNA complex, and the VP16-induced complex containing hamster HCF (VIC) are indicated. The asterisk ( ${ }^{*}$ ) indicates a weak, HCF-independent, VP16-Oct-1 POU domain complex (see lane 2). 
transcription at the permissive temperature (albeit only three-fold) but failed to activate transcription at the nonpermissive temperature (cf. lanes 5 and 6 , and 7 and 8 ), even though general transcription was apparently not grossly disrupted because an internal reference $\alpha$-globin promoter remained active. These results indicate that the single tsBN67 HCF mutation affects not only cell proliferation but also transcriptional activation by VP16. Consistent with this conclusion, in tsBN67 cells rescued for growth at the nonpermissive temperature (called $\mathrm{mR} 19-2$ ), VP16 transcriptional activation is also restored at the nonpermissive temperature (cf. lanes 9 and 10).

VP16 might fail to activate transcription in tsBN67 cells at the nonpermissive temperature because (1) formation of the VP16-induced complex is impaired, or (2) HCF in the VP16-induced complex is deficient for a function required to activate transcription. To discriminate between these two possibilities, we assayed the ability of cell extracts prepared from wild-type and tsBN67 BHK21 cells grown at $33.5^{\circ} \mathrm{C}$ or at $39.5^{\circ} \mathrm{C}$ for $48 \mathrm{hr}$ to support VP16-induced complex formation in an electrophoretic mobility retardation assay, as shown in Figure 4B. The relative levels of VP16-induced complex formation (labeled VIC) were similar to the relative levels of VP16dependent activation of transcription in Figure 4A: VP16-induced complex formation was readily detected in wild-type cells grown at either $33.5^{\circ} \mathrm{C}$ (lanes 3-5) or $39.5^{\circ} \mathrm{C}$ (lanes $6-8$ ), but was significantly reduced in the extracts from tsBN67 cells grown at $33.5^{\circ} \mathrm{C}$ (lanes 9-11) and below our detection levels in tsBN67 cells grown at $39.5^{\circ} \mathrm{C}$ (lanes 12-14). Thus, VP16 apparently fails to activate transcription in tsBN67 cells at the nonpermissive temperature because the mutant HCF does not effectively support formation of the VP16-induced complex. Consistent with this hypothesis, VP16-induced complex formation is restored in the rescued mR19-2 tsBN67 cell line (data not shown).

\section{tsBN67 cells arrest at the nonpermissive temperature primarily with a 2C DNA content}

To characterize the cell-cycle status of arrested tsBN67 cells, we performed fluorescence-activated cell sorting (FACS) on cycling and arrested cells. Figure 5A shows a FACS analysis of parallel tsBN67 cultures incubated at either $33.5^{\circ} \mathrm{C}$ or $39.5^{\circ} \mathrm{C}$ for $48 \mathrm{hr}$. At the permissive temperature, tsBN67 cells show a typical profile for an asynchronous population of cycling BHK cells, with $42.8 \%$, $43.2 \%$, and $14 \%$ of the cells in $G_{1}, S$, and $G_{2} / M$, respectively. In contrast, after incubation at the nonpermissive temperature, many fewer tsBN67 cells were in S phase $(10.9 \%)$. Instead, the large majority $(73.1 \%)$ had a $2 \mathrm{C}$ DNA content, consistent with an arrest in either $G_{1}$ or $\mathrm{G}_{0}$. The $4 \mathrm{C}$ DNA content peak ( $16 \%$ of cells) may represent tsBN67 cells arrested in $G_{2} / M$ or alternatively may represent tetraploid $G_{1}$ cells. We have not distinguished between these possibilities. In either case, however, these results indicate that after initiation of DNA replication at the nonpermissive temperature, the majority of tsBN67 cells do not arrest until sometime after its
A

$33.5^{\circ} \mathrm{C}$

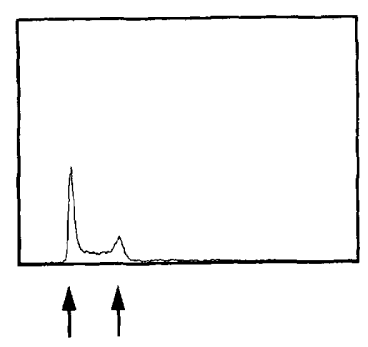

$2 C 4 \mathrm{C}$ $39.5^{\circ} \mathrm{C}$

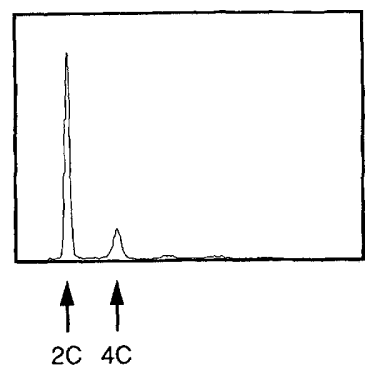

DNA content

B

1

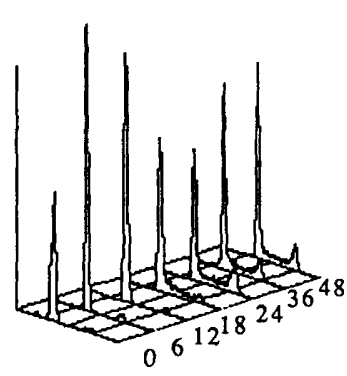

2

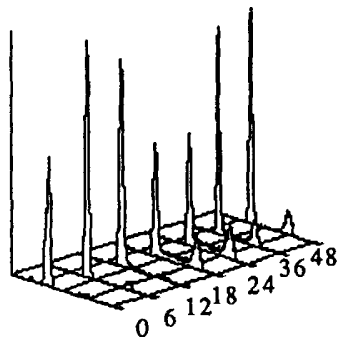

3

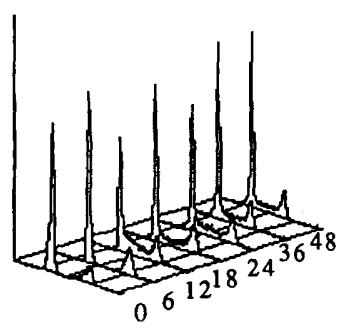

4

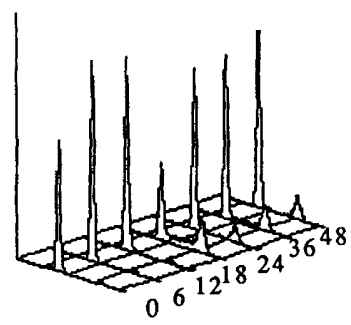

Figure 5. Cell cycle analysis of tsBN67 cells. (A) DNA content FACS analysis of growing and arrested tsBN67 cells. Exponentially growing cultures of tsBN67 cells were seeded at $1 \times 10^{6} /$ $100-\mathrm{mm}$ dish and grown at $33.5^{\circ} \mathrm{C}$. After 2 days incubation, half the plates were shifted to $39.5^{\circ} \mathrm{C}$, and after $48 \mathrm{hr}$, cells held at each temperature were prepared for FACS analysis as described in Materials and Methods. (B) DNA content of tsBN67 and wildtype $\mathrm{BHK} 21$ cells traversing the cell cycle following release from serum starvation at $39.5^{\circ} \mathrm{C}$. Exponentially growing cultures of wild-type BHK21 (panel 3) and tsBN67 (panels 1,2,4) cells were incubated in DMEM medium containing $0.25 \%$ calf serum for $48 \mathrm{hr}$ at $33.5^{\circ} \mathrm{C}$ (panels 1,2 ) or $18 \mathrm{hr}$ at $33.5^{\circ} \mathrm{C}$ followed by $30 \mathrm{hr}$ at $39.5^{\circ} \mathrm{C}$ (panels 3,4 ), after which the medium was exchanged for preheated complete medium containing $10 \% \mathrm{fe}$ tal calf serum, and the cells were incubated further at $33.5^{\circ} \mathrm{C}$ (panel 1) or $39.5^{\circ} \mathrm{C}$ (panels 2-4). At the indicated times following serum addition, cells were prepared for FACS analysis as described in Materials and Methods.

completion, mostly with a 2C DNA content characteristic of $G_{1}$ and $G_{0}$ cells.

The growth curves in Figure 1 show that there is a lag of a few cell divisions before tsBN67 cell-cycle arrest 
occurs at the nonpermissive temperature. We imagine two possible explanations for this delay: (1) a proliferation-independent mechanism in which, for example, it simply takes time for the elevated temperature to inactivate the tsBN67 HCF protein, or (2) proliferation-dependent mechanisms in which proliferation at the nonpermissive temperature is required either to inactivate the tsBN67 HCF protein or to inactivate/deplete a hypothetical protein whose expression is regulated by HCF. To discriminate between these proliferation-independent and -dependent mechanisms, we incubated the tsBN67 cells at the permissive temperature in low serum $(0.25 \%)$ for $18 \mathrm{hr}$ to cause $\mathrm{G}_{0}$ arrest and subsequently continued maintaining the arrested cells in low serum for $30 \mathrm{hr}$ but at the nonpermissive temperature. If the delay is proliferation independent then incubation of the serum-arrested cells at the nonpermissive temperature should still impair subsequent cell proliferation after addition of serum, whereas if the tsBN67 phenotype is dependent on proliferation at the nonpermissive temperature then release from serum arrest at the nonpermissive temperature should result in one or more rounds of cell division.

Figure 5B (panel 4) shows a series of FACS analyses resulting from time points taken at and after addition of serum in such an experiment. At the time of serum addition, the arrested tsBN67 cells contained primarily a 2C DNA content (0-hr sample; panel 4), consistent with arrest in $\mathrm{G}_{0}$. The refed tsBN67 cells entered $S$ phase at the nonpermissive temperature with some delay compared with wild-type BHK21 cells (cf. 12-hr profiles; panels 3 and 4). The tsBN67 cells subsequently traversed about one round of the cell cycle before accumulating with primarily a $2 \mathrm{C}$ DNA content (see 48 -hr tsBN67 profile in Fig. 5B, panel 4). These findings suggest that the tsBN67 cell-cycle arrest is dependent on proliferation at the nonpermissive temperature; perhaps passage through the cell cycle is required to inactivate HCF or to inactivate or deplete a critical cellular factor that is regulated by HCF. This hypothesis was confirmed further by the finding that tsBN67 cells incubated at the permissive temperature in low serum for $48 \mathrm{hr}$ were arrested after about one round of the cell cycle at the nonpermissive temperature, after release from serum starvation (cf. panel 2, release from serum starvation at nonpermissive temperature, and panel 1, release from serum starvation at the permissive temperature).

Early $G_{1}$ gene expression profiles are similar in tsBN67 cells arrested by nonpermissive temperature or serum starvation

To characterize the cell-cycle status of tsBN67 cells arrested by incubation at the nonpermissive temperature, we compared the steady-state levels of c-jun, fra-1, and c-myc transcripts in cycling and arrested tsBN67 cells by Northern blot analysis as shown in Figure 6. These three genes represent examples of IE (c-jun) and delayed-early (c-myc and fra-1) genes expressed during $\mathrm{G}_{1}$ (Lau and Nathans 1991). Asynchronous cycling cultures of

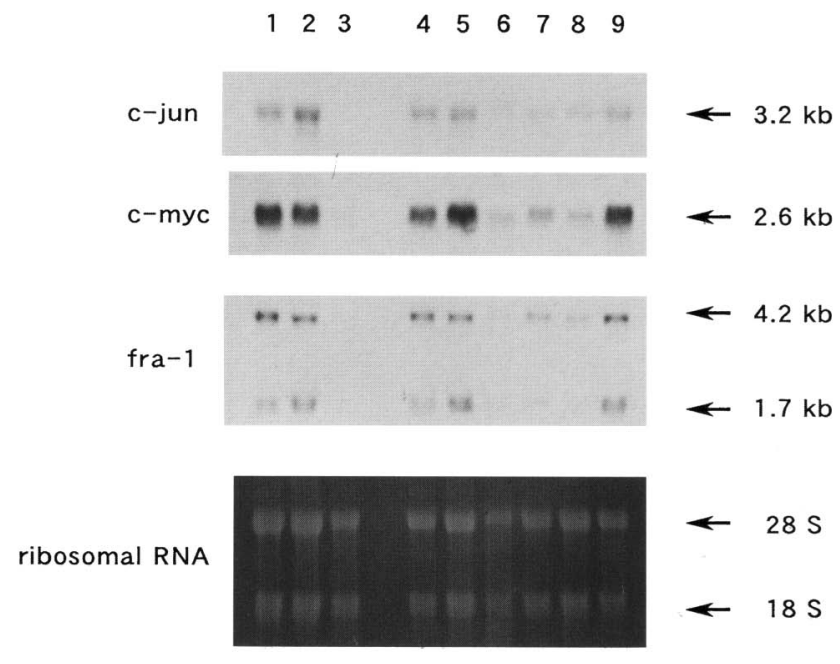

Figure 6. Northern blots of RNA prepared from growing and arrested cultures of wild-type BHK21 and tsBN67 cells probed for c-jun, fra-1 and c-myc transcripts. Asynchronous cultures of wild-type BHK21 (lanes 1-3) and tsBN67 (lanes 4-9) cells were seeded at $33.5^{\circ} \mathrm{C}$. After 2 days, one series of cultures was shifted to $39.5^{\circ} \mathrm{C}$ and total RNA was prepared after incubation for 0 (lanes 1,4), 12 (lane 5), 24 (lane 6), and 48 (lanes 2,7) hr. Another series of cultures was incubated for $48 \mathrm{hr}$ at $33.5^{\circ} \mathrm{C}$ in normal medium (lane 9) or in low serum medium (lanes 3,8), and then total RNA was isolated. RNAs were probed by Northern blotting using probes derived from c-jun, fra-1, and c-myc cDNAs as described in Materials and Methods. The levels and integrity of the RNA in each sample were examined by staining the rRNA with ethidum bromide as shown in the bottom panel.

tsBN67 cells were shifted from $33.5^{\circ} \mathrm{C}$ to $39.5^{\circ} \mathrm{C}$, and total RNA was isolated after $0,12,24$, and $48 \mathrm{hr}$ incubation (Fig. 6, lanes 4-7). As controls, asynchronous cycling cultures of wild-type BHK21 cells were incubated at $39.5^{\circ} \mathrm{C}$ for $48 \mathrm{hr}$ (lane 2), and wild-type $\mathrm{BHK} 21$ and tsBN67 cells were incubated at $33.5^{\circ} \mathrm{C}$ in low serum medium for $48 \mathrm{hr}$ to arrest cells at $\mathrm{G}_{0} / \mathrm{G}_{1}$ (lanes 3 and 8 , respectively). Compared to asynchronous cycling cells (lanes 1,4), the level of c-jun, c-myc, and fra-1 transcripts dropped significantly in both wild-type BHK21 and tsBN67 cells incubated in low serum medium at $33.5^{\circ} \mathrm{C}$ (lanes 3,8$)$. At $39.5^{\circ} \mathrm{C}$, no reduction of c-jun, c-myc, and fra-1 transcripts was observed even after incubation for $48 \mathrm{hr}$ in wild-type BHK21 cells (lane 2); in tsBN67 cells, however, the level of these transcripts dropped significantly after $24 \mathrm{hr}$ incubation (cf. lanes 4 and 5 to lanes 6 and 7)-levels similar to those in the cultures arrested by serum starvation. The similarity in $\mathrm{G}_{1}$-gene expression pattern between the temperature- and serum-arrested tsBN67 cells suggests that tsBN67 cells arrested at $39.5^{\circ} \mathrm{C}$ enter a $\mathrm{G}_{0}$-like state.

\section{Discussion}

We have identified the gene and mutation responsible for the temperature-sensitive growth-arrest phenotype of the hamster tsBN67 BHK cell line. The mutation is a 
single amino acid substitution-proline to serine- at position 134 of HCF. These results demonstrate that in addition to a role in HSV infection, HCF has a role in cell proliferation. Remarkably, at the nonpermissive temperature, the single tsBN67 amino acid substitution interferes with the role of HCF in both cell cycle progression and activation of transcription by VP16, suggesting that parallels exist in how HCF promotes these two processes. These insights into the role of HCF in cell proliferation were made possible by the conditional phenotype of the tsBN67 mutation.

\section{$H C F$ may function as a determinant for entry into $G_{O}$}

The phenotype of the cell-cycle-arrested tsBN67 cells displays a number of interesting properties. First, the arrest is not immediate at the nonpermissive temperature, and even if tsBN67 cells arrested by serum starvation are incubated at high temperature, they will resume cycling after addition of serum. Second, based on DNA content, the arrest is primarily in $G_{1}$ or $G_{0}$, and the early $G_{1}$ gene expression pattern of temperature-arrested cells suggests that they enter a $G_{0}$-like state. Third, arrested tsBN67 cells are stable at the nonpermissive temperature.

At first, the delay in tsBN67-cell arrest at the elevated temperature seems paradoxical given that in the original isolation protocol, cells that proliferate at elevated temperature were selected against by treatment with the cytotoxic base-analog 5-fluoro-2-deoxyuridine (Nishimoto and Basilico 1978). Perhaps the arrest of tsBN67-cell proliferation is stochastic at the elevated temperature such that some cells arrest early and, because these cells are very stable at the elevated temperature, once arrested survive the selection protocol efficiently. This possibility would explain why tsBN67 cells were only isolated after three rounds of 5-fluoro-2-deoxyuridine selection, whereas other cell lines such as tsBN2, which have a rapid cell-cycle arrest phenotype but are unstable at the elevated temperature, appeared after the first round of selection and disappeared after the second and third rounds of selection (Nishimoto and Basilico 1978).

The ability of tsBN67 cells released from arrest by serum starvation to enter $\mathrm{S}$ phase, irrespective of preincubation at the nonpermissive temperature (Fig. 5B), suggests that HCF acts prior to the serum-arrest point of the cell cycle. This conclusion is consistent with the finding that the expression pattern of early $G_{1}$ genes in tsBN67 cells arrested at the nonpermissive temperature is similar to that of tsBN67 cells arrested by serum starvation (Fig. 6). Thus, tsBN67 cells apparently arrest in a $\mathrm{G}_{0}-$ like state at the nonpermissive temperature. Perhaps, $\mathrm{HCF}$ is required for promoting passage from $G_{0}$ to $G_{1}$. The $G_{0}$ like properties of arrested tsBN67 cells may be the reason for their high survival rate at the nonpermissive temperature because $G_{0}$ cells are known to survive for long periods of time as growth-arrested cells. A series of genes that are expressed specifically in growth-arrested cells (GAS genes) has been described (Schneider et al. 1988). Studies of their expression in temperature-arrested
tsBN67 cells should further define the nature of the tsBN67 arrest point and its relationship to $G_{0}$.

\section{VP16 targets a cell-cycle regulator}

In contrast to some temperature-sensitive cell-cycle arrest mutations that lead to instability of the mutant protein (see, e.g., Nishitani et al. 1991; Nakashima et al. 1993), the tsBN67 mutation has no apparent effect on the stability, maturation, or coassociation of processed HCF fragments. It does, however, apparently affect the ability of HCF to stabilize the VP16-induced complex because HCF-containing extracts prepared from tsBN67 cells incubated at the nonpermissive temperature fail to promote VP16-induced complex formation. This defect explains why VP16 does not activate transcription effectively in these cells at the nonpermissive temperature, which in turn presents strong evidence that HCF is important for transcriptional activation by VP16 in vivo and therefore a key regulator of HSV IE gene transcription.

The parallel effect of the tsBN67 mutation on VP16 function and cell proliferation raises the possibility that VP16 associates with HCF by mimicking a cellular protein that regulates cell proliferation. By analogy to the VP16-induced complex in HSV-infected cells, the cellular protein mimicked by VP16 may form a multiprotein complex with HCF and regulate transcription in uninfected cells. Because there is currently no evidence that Oct-1 interacts with HCF in uninfected cells, we do not hypothesize that Oct-1 is a member of such an HCFcontaining regulatory complex. We do suggest, however, that such a regulatory complex explains the characteristic delay in growth arrest of tsBN67 cells at the nonpermissive temperature because continued cell proliferation may be required to deplete a cellular factor regulated by this putative HCF-containing complex that promotes cell proliferation, particularly through the $G_{0} / G_{1}$ decision point. The identification of a cellular protein mimicked by VP16 will be particulary interesting, because it may help clarify the molecular mechanisms by which cells decide between $G_{0}$ and $G_{1}$.

\section{The VP16-HCF interaction: a sensor of cell status during HSV infection}

Unlike obligate lytic viruses, HSV can undergo a productive lytic infection pathway or be latent for long periods. This dual course of infection is influenced by the status of the infected cell. Infection of epithelial cells often leads to productive lytic infection, whereas infection of neurons, in particular those in the trigeminal and dorsal root ganglia, leads to latent infection (for review, see Roizman and Sears 1987). By associating with two cellular factors, HCF and Oct-1, and subsequently activating transcription of HSV IE genes, VP16 may serve as a sensor of cell status that contributes to the viral decision to undergo a productive lytic infection or become latent. The function of HCF revealed by the tsBN67 mutationthat it promotes progression through $\mathrm{G}_{1}$ - suggests that 
it is an excellent target for the capacity of VP16 as a cell-status sensor because cells infected by HSV are commonly in the $G_{0}$ or $G_{1}$ phases of the cell cycle.

In cultured cells, HSV grows productively in $\mathrm{G}_{1}$ cells, promoting progression through $\mathrm{G}_{1}$ (Hilton et al. 1995) but inhibiting entry into $S$ phase /de Bruyn Kops and Knipe 1988). In these cells, VP16 originating from the tegument of the infecting virion can associate with HCF and promote productive infection. In animals, neurons of the trigeminal ganglion, in which HSV establishes a latent infection, are predominantly $\mathrm{G}_{0}$ cells. In such cells, if $\mathrm{HCF}$ is inactive, tegument-derived VP16 may fail to promote productive infection. In latently infected neurons, VP16-HCF association may then serve as a key regulator for entry into productive viral infection by responding to the $G_{0} / G_{1}$ status of the infected cell. Knipe and colleagues (Kosz-Vnenchak et al. 1993) have suggested that during latent infection of trigeminal ganglion neurons, HSV DNA is replicated at low levels, resulting in low-level expression of late gene products such as VP16. Under such conditions of low-level replication and late-gene expression, subtle changes in the abundance of active HCF could influence the ability of VP16 to amplify the reactivation process and thus respond to changes in the $G_{0} / G_{1}$ status of the latently infected cell. The association of VP16 with HCF appears ideally suited for such a regulatory role because of the involvement of HCF in the $G_{1}$ phase as revealed by the tsBN67 mutation.

\section{Materials and methods \\ Cell lines and cell culture}

All cell lines were cultured in Dulbecco's modified Eagle medium (DMEM) supplemented with $10 \%$ calf serum or $10 \%$ fetal calf serum in a humidified atmosphere containing $10 \% \mathrm{CO}_{2}$. tsBN67 cells were maintained at $33.5^{\circ} \mathrm{C}$, the permissive temperature, and $\mathrm{ts}^{+}$cells were selected at $39.5^{\circ} \mathrm{C}$, the nonpermissive temperature.

\section{Stable transformantion of tsBN67 cells}

High molecular weight HeLa-cell DNA (20 $\mu$ g/dish), or cloned genomic DNA or cDNA expression clones (2 $\mathrm{g} / \mathrm{dish})$, were transfected into tsBN67 cells (seeded at $2 \times 10^{5}$ cells $/ 100-\mathrm{mm}$ dish) along with the neo ${ }^{r}$ pSV2neo expression vector $(2 \mu \mathrm{g} / \mathrm{dish})$, using either the calcium phosphate coprecipitation method (genomic DNA) or a modification of the Chen and Okayama method (cDNA expression plasmids), as described previously (Watanabe et al. 1991). Transfected cells were incubated at $33.5^{\circ} \mathrm{C}$ for $18 \mathrm{hr}$, washed with TD /Tris-buffered saline without $\mathrm{Ca}^{2+}$ and $\mathrm{Mg}^{2+}$, and, after a further $48 \mathrm{hr}$ incubation at $33.5^{\circ} \mathrm{C}$, cultured in the presence of $\mathrm{G} 418(800 \mu \mathrm{g} / \mathrm{ml})$ at either $33.5^{\circ} \mathrm{C}$ or $39.5^{\circ} \mathrm{C}$. The number of colonies was determined after incubation for about 2 weeks as described (Watanabe et al. 1991).

\section{Construction and screening of DNA libraries}

A library of genomic DNA clones from $\mathrm{ts}^{+}$tsBN67 transformants was constructed in the $\lambda$ DashII vector (Stratagene, Inc.) and screened for human sequences using a human Alu repeatcontaining plasmid as probe. A BHK21-cell cDNA library, con- structed in the $\lambda \mathrm{gt} 10$ vector, was then screened, using an Alufree region from human genomic DNA clone $5 / \lambda$ DashII, as described previously (Watanabe et al. 1991).

\section{HCF immunoprecipitation and immunoblotting}

A 19-amino-acid peptide with the sequence CMASAVSPANLPAVLLQPR, containing HCF residues 1-18 (underlined) was synthesized, coupled to keyhole limpet hemocyanin, and inoculated into a New Zealand white rabbit with $300 \mu \mathrm{g}$ of antigen in Freund's incomplete adjuvant at 3-week intervals (Harlow and Lane 1988). An immune response was detected by mobility retardation analysis. HCF immunoprecipitation was performed with this $\alpha \mathrm{HCF}_{\mathrm{N}}$ antipeptide antiserum, referred to as $\alpha \mathrm{HCF}_{\mathrm{N} 18}$, at a 1:100 dilution. Immunoprecipitation from native and denatured extracts and subsequent immunoblotting were performed as described previously (Wilson et al. 1993a, 1995b).

\section{Transient expression assay}

Wild-type and tsBN67 BHK cells grown at $33.5^{\circ} \mathrm{C}$ were seeded at $1.2 \times 10^{6}$ cells $/ 100-\mathrm{mm}$ dish for assay at $33.5^{\circ} \mathrm{C}$, and $6 \times 10^{5}$ cells $/ 100-\mathrm{mm}$ dish for assay at $39.5^{\circ} \mathrm{C}$. Immediately after seeding, the cells were placed at the assay temperature (either $33.5^{\circ} \mathrm{C}$ or $39.5^{\circ} \mathrm{C}$ ) and then transfected $24 \mathrm{hr}$ later by calcium phosphate coprecipitation essentially as described by Cleary et al. (1993). Briefly, each plate was transfected with $4 \mu \mathrm{g}$ of the VP16-responsive $\beta$-globin-related reporter plasmid $\mathrm{pU} 2 / \beta$ $6 \times T_{A A T}$, along with $200 \mathrm{ng}$ of the internal reference plasmid $\mathrm{p} \alpha 4 \mathrm{x}(\mathrm{A}+\mathrm{C}), 80 \mathrm{ng}$ of a wild-type VP16 expression plasmid (pCGNVP16) where appropriate, and pUC119 carrier DNA to a total of $20 \mu \mathrm{g}$ DNA. Cells were washed with $1 \times$ PBS $/ 1$ mM EGTA $24 \mathrm{hr}$ post-transfection and collected $12 \mathrm{hr}$ later. To measure reporter and internal reference transcripts, cytoplasmic RNA was prepared by the NP-40 lysis method and probed with radiolabeled antisense $\beta$-globin $(\beta 134)$ and $\alpha$-globin $(\alpha 98)$ probes (Cleary et al. 1993). Unprotected RNA was digested with RNase $A$ and $T_{1}$, and the resulting protected RNAs separated on a $6 \%$ denaturing polyacrylamide gel. Levels of reporter gene transcription were quantitated using the Fuji BAS1000 PhosphorImager and normalized to the level of the internal reference $\alpha$-globin RNA.

\section{Electrophoretic mobility retardation assays}

Extract preparation and electrophoretic mobility retardation assays were performed as described (Wilson et al. 1993a), except that fetal bovine serum was not added to the binding reactions.

\section{FACS analysis}

To determine cellular DNA content, cells were removed from plates with trypsin, washed with PBS, fixed with $50 \%$ ethanol, treated with RNase A $(1 \mathrm{mg} / \mathrm{ml})$, and stained with propidium iodide $(0.1 \%$ sodium citrate, propidium iodide $50 \mu \mathrm{g} / \mathrm{ml})$. Cellular DNA content were then analyzed by FACScan (BectonDickinson).

\section{Northern analysis}

RNA filters were prepared as described previously (Watanabe et al. 1991) and prehybridized with $100 \mu \mathrm{g} / \mathrm{ml}$ of salmon sperm DNA at $42^{\circ} \mathrm{C}$ for $18-24 \mathrm{hr}$ in buffer containing $0.5 \%$ SDS, $50 \%$ formamide, $6 \times$ SSC $10.15 \mathrm{M} \mathrm{Nacl}, 0.015 \mathrm{M}$ sodium citrate at $\mathrm{pH}$ 7.0), 5x Denhardt's solution, and then incubated for $24-48 \mathrm{hr}$, with ${ }^{32}$ P-labeled c-jun, c-myc, and fra-1 cDNA fragments de- 
rived as follows: c-jun [2.6-kb RsrII-ScaI fragment of murine c-jun (Ryder and Nathans 1988)], c-myc [1.5-kb SacI-HindIII fragment of murine c-myc (Nakabeppu et al. 1988/], and fra-1 [0.4-kb KpnI-XbaI fragment of murine fra-1 (Cohen and Curran 1988)]. After hybridization, the filters were washed in the following manner: twice in $2 \times$ SSC plus $0.1 \%$ SDS for $30 \mathrm{~min}$ at room temperature, twice in $1 \times$ SSC plus $0.1 \%$ SDS for $30 \mathrm{~min}$ at $70^{\circ} \mathrm{C}$, and then in $0.2 \times$ SSC plus $0.1 \%$ SDS at $70^{\circ} \mathrm{C}$ for $60 \mathrm{~min}$. Finally, filters were dried and analyzed with a Fuji Bioimage analyzer.

\section{Acknowledgments}

We thank the Human Genome Center (Institute of Medical Science, Tokyo University) for suppling the sequence data. S. Atanasoski and $\mathrm{G}$. Binns for help in preparing the $\alpha \mathrm{HCF}_{\mathrm{N} 18}$ antiserum, and $M$. Cleary for reagents. This work was supported by Grants-in-Aid for Scientific Research and for Cancer Research from the Ministry of Education, Science and Culture of Japan to T.N. and U.S. Public Health Service grant CA13106 from the National Cancer Institute to W.H. T.N. thanks Dr. H. Sumimoto (Faculty of Medicine, Kyushu University) for a general suggestion regarding transcription factors.

The publication costs of this article were defrayed in part by payment of page charges. This article must therefore be hereby marked "advertisement" in accordance with 18 USC section 1734 solely to indicate this fact.

\section{References}

Cleary, M.A., S. Stern, M. Tanaka, and W. Herr. 1993. Differential positive control by Oct-1 and Oct-2: Activation of a transcriptionally silent motif through Oct-1 and VP16 corecruitment. Genes \& Dev. 7: 72-83.

Cohen, D.R. and T. Curran. 1988. fra-1: A serum-inducible, cellular immediate-early gene that encodes a Fos-related antigen. Mol. Cell. Biol. 8: 2063-2069.

de Bruyn Kops, A. and D.M. Knipe. 1988. Formation of DNA replication structures in herpes virus-infected cells requires a viral DNA binding protein. Cell 55: 857-868.

Frattini, A., A. Chatterjee, S. Faranda, M.G. Sacco, A. Villa, G.E. Herman, and P. Vezzoni. 1996. The chromosome localization and the HCF repeats of the human Host Cell Factor gene (HCFC1) are conserved in the mouse homologue. Genomics 32: $277-280$.

Gerster, T. and R.G. Roeder. 1988. A herpesvirus trans-activating protein interacts with transcription factor OTF-1 and other cellular proteins. Proc. Natl. Acad. Sci. 85: 63476351.

Harlow, E. and D. Lane. 1988. Antibodies: A laboratory manual. Cold Spring Harbor Laboratory Press, Cold Spring Harbor, NY.

Herr, W. 1992. Oct-1 and Oct-2: Differential transcriptional activation by proteins that bind to the same DNA sequence: In Transcriptional regulation led. S.L. McKnight and K.R. Yamamotol, pp.1103-1135, Cold Spring Harbor Laboratory Press, Cold Spring Harbor, NY.

Hilton, M.J., D. Mounghane, T. McLean, N.V. Contractor, J. O'Neil, K. Carpenter, and S.L. Bachenheimer. 1995. Induction by herpes simplex virus of free and heteromeric forms of E2F transcription factor. Virology 213: 624-638.

Ito, T., T. Nakamura, H. Maki, and M. Sekiguchi. 1994. Roles of transcription and repair in alkylation mutagenesis. Mutat. Res. 314: 273-285.

Kai, R., M. Ohtsubo, M. Sekiguchi, and T. Nishimoto. 1986.
Molecular cloning of a human gene that regulates chromosome condensation and is essential for cell proliferation. Mol. Cell. Biol. 6: 2027-2032.

Katan, M., A. Haigh, C.P. Verrijzer, P.C. van der Vliet, and P. O'Hare. 1990. Characterization of a cellular factor which interacts functionally with Oct-1 in the assembly of a multicomponent tanscription complex. Nucleic Acids Res. 18: $6871-6880$.

Kosz-Vnenchak, M., J. Jacobson, D.M. Coen, and D.M. Knipe. 1993. Evidence for a novel regulatory pathway for herpes simplex virus gene expression in trigeminal ganglion neurons. I. Virol. 67: 5383-5393.

Kristie, T.M. and P.A. Sharp. 1990. Interactions of the Oct-1 POU subdomains with specific DNA sequences and with the HSV $\alpha$-transactivator protein. Genes \& Dev. 4: 2383-2396.

1993. Purification of the cellular C1 factor required for the stable recognition of the Oct-1 homeodomain by the herpes simplex virus $\alpha$-trans-induction factor (VP16). J. Biol. Chem. 268: 6525-6534.

Kristie, T.M., J.H. Lebowitz, and P.A. Sharp. 1989. The octamerbinding proteins form multi-protein-DNA complexes with the HSV $\alpha$-TIF regulatory protein. EMBO I. 8: 4229-4238.

Kristie, T.M., J.L. Pomerantz, T.C. Twomey, S.A. Parent, and P.A. Sharp. 1995. The cellular C1 factor of the herpes simplex virus enhancer complex is a family of polypeptides. $J$. Biol. Chem. 270: 4387-4394.

Lau, L.F. and D. Nathans. 1991. Genes induced by serum growth factors, In Molecular aspects of cellular regulation, (ed. P. Cohen and J.C. Foulkes|, vol. 6, p. 257-293. Elsevier, Amsterdam, The Netherlands.

Marcus, M., A. Fainsod, and G. Diamond. 1985. The genetic analysis of mammalian cell-cycle mutants. Annu. Rev. Genet. 19: 389-421.

Nakabeppu, Y., K. Ryder, and D. Nathans. 1988. DNA binding activities of three murine Jun proteins: Stimulation by Fos. Cell 55: 907-915.

Nakashima, T., T. Sekiguchi, A. Kuraoka, K. Fukushima, Y. Shibata, S. Komiyama, and T. Nishimoto. 1993. Molecular cloning of a human cDNA encoding a novel protein, DAD1 whose defect causes apoptotic cell death in hamster BHK2l cells. Mol. Cell. Biol. 13: 6367-6374.

Nishimoto, T. and C. Basilico. 1978. Analysis of a method for selecting temperature sensitive mutants of BHK cells. Somat. Cell Genet. 4: 323-340.

Nishimoto, T., T. Sekiguchi, R. Kai, K. Yamashita, T. Takahashi, and M. Sekiguchi. 1982. Large-scale selection and analysis of temperature sensitive mutants for cell reproduction from BHK cells. Somat. Cell Genet. 8: 811-824.

Nishitani, H., M. Ohtsubo, K. Yamashita, H. Iida, J. Pines, H. Yasudo, Y. Shibata, T. Hunter, and T. Nishimoto. 1991. Loss of RCCl, a nuclear DNA-binding protein, uncouples the completion of DNA replication from the activation of cdc2 protein kinase and mitosis. EMBO I. 10: 1555-1564.

O'Hare, P. 1993. The virion transactivator of herpes simplex virus. The alpha-herpesviruses Semin. Virol. 4: 145-155.

Roizman, B. and A.E. Sears. 1987. An inquiry into the mechanisms of herpes simplex virus latency. Annu. Rev. Microbiol. 41: $543-571$.

Ryder, K. and D. Nathans. 1988. Induction of protooncogene c-jun by serum growth factors. Proc. Natl. Acad. Sci. 85: 8464-8467.

Schneider, C., R.M. King, and L. Philipson. 1988. Genes specifically expressed at growth arrest of mammalian cells. Cell 54: 787-793.

Seki, T., K. Yamashita, H. Nishitani, T. Takagi, P. Russell, and T. Nishimoto. 1992. Chromosome condensation caused by 
loss of $\mathrm{RCCl}$ function requires the cdc25C protein that is located in the cytoplasm. Mol. Biol. Cell 3: 1373-1388.

Stern, S. and W. Herr. 1991. The herpes simplex virus transactivator VP16 recognizes the Oct-1 homeo domain: Evidence for a homeo domain recognition subdomain. Genes \& Dev. 5: 2555-2566.

Thompson, C.C. and S.L. McKnight. 1992. Anatomy of enhancer. Trends Genet. 8: 232-236.

Uchida, S., T. Sekiguchi, H. Nishitani, K. Miyauchi, M. Ohtsubo, and T. Nishimoto. 1990. Premature chromosome condensation is induced by a point mutation in the hamster RCC1 gene. Mol. Cell. Biol. 10: 577-584.

Watanabe, M., N. Furuno, M. Goebl, M. Go, K. Miyauchi, T. Sekiguchi, C. Basilico, and T. Nishimoto. 1991. Molecular cloning of the human gene, CCG2, that complements the BHK-derived temperature-sensitive cell cycle mutant tsBN63: Identity of CCG2 with the human X chromosomal SCAR/RPS4X gene. I. Cell Sci. 100: 35-43.

Watanabe, M., A.R. Zinn, D.C. Page, and T. Nishimoto. 1993. Functional equivalence of human X-and Y-encoded isoforms of ribosomal protein $S 4$ consistent with a role in Turner syndrome. Nature Genetics 4: 268-271.

Wilson, A.C., K. LaMarco, M.G. Peterson, and W. Herr. 1993a. The VP16 accessory protein HCF is a family of polypeptides processed from a large precursor protein. Cell 74: 115-125.

Wilson, A.C., M.A. Cleary, J.-S. Lai, K. LaMarco, M.G. Peterson, and W. Herr. 1993b. Combinatorial control of transcription: The herpes simplex virus VP16-induced complex. Cold Spring Harbor Symp. Quant. Biol. 58: 167-178.

Wilson, A.C., J.E. Parrish, H.F. Massa, D.L. Nelson, B.J. Trask, and W. Herr. 1995a. The gene encoding the VP16-accessory protein HCF (HCFC1) resides in human Xq28 and is highly expressed in fetal tissues and the adult kidney. Genomics 25: 462-468.

Wilson, A.C., M.G. Peterson, and W. Herr. 1995b. The HCF repeat is an unusual proteolytic cleavage signal. Genes \& Dev. 9: 2445-2458.

Xiao, P. and J.P. Capone. 1990. A cellular factor binds to the herpes simplex virus type 1 transactivator Vmw65 and is required for Vmw65-dependent protein-DNA complex assembly with Oct-1. Mol. Cell. Biol. 10: 4974-4977. 


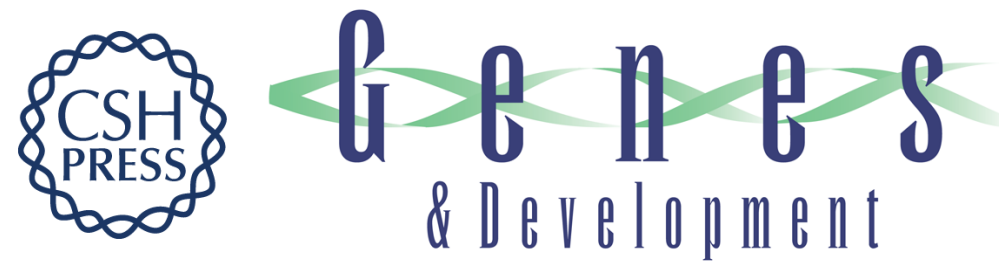

\section{A single-point mutation in HCF causes temperature-sensitive cell-cycle arrest and disrupts VP16 function.}

H Goto, S Motomura, A C Wilson, et al.

Genes Dev. 1997, 11:

Access the most recent version at doi:10.1101/gad.11.6.726

References This article cites 35 articles, 17 of which can be accessed free at: http://genesdev.cshlp.org/content/11/6/726.full.html\#ref-list-1

License

Email Alerting

Service

Receive free email alerts when new articles cite this article - sign up in the box at the top right corner of the article or click here.

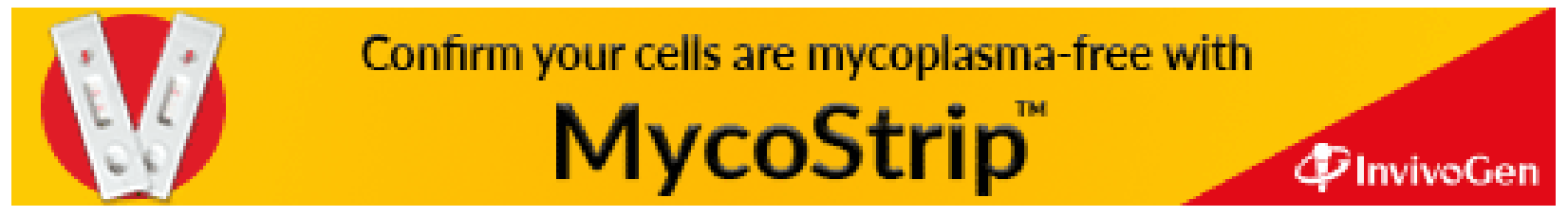

